\title{
Natural infection by Trypanosoma cruzi in dogs located in Ituberá, Southern Bahia, Brazil
}

\section{Infecção natural por Trypanosoma cruzi em cães domiciliados de Ituberá, Sul da Bahia, Brasil}

\author{
Graziela Baroni de Souza ${ }^{1 *}$; Paula Elisa Brandão Guedes ${ }^{1}$; Thaís Nascimento de \\ Andrade Oliveira $^{1}$; Fábio Santos Carvalho ${ }^{2}$; George Rêgo Albuquerque ${ }^{3}$; Fabiana \\ Lessa Silva ${ }^{3}$
}

\begin{abstract}
Resumo
A Doença de Chagas, causada pelo protozoário flagelado Trypanosoma cruzi, é uma antropozoonose de grande importância para a saúde pública. Diversas espécies de mamíferos são reservatórios do parasita, incluindo o cão. O objetivo deste trabalho foi verificar a infecção natural por T. cruzi na população de cães do município de Ituberá, Bahia. Foram avaliados 392 cães domiciliados, em todos os bairros do município, dos quais foram coletados $5 \mathrm{~mL}$ de sangue para realização do diagnóstico molecular. A amplificação do DNA de T. cruzi foi através da Reação em Cadeia da Polimerase (PCR), com os primers $\mathrm{P} 35$ e P36, que amplificam um fragmento de $330 \mathrm{pb}$. Os produtos das PCRs foram submetidos à eletroforese em gel de agarose a $2 \%$ contendo Sybr (Invitrogen ${ }^{\circledR}$ ). Dos 392 cães avaliados, apenas $2(0,51 \%)$ animais, um macho e uma fêmea, foram positivos no diagnóstico molecular de T. cruzi. Conclui-se com esse estudo que há cães naturalmente infectados pelo T. cruzi no município de ItuberáBahia e que este achado constitui um alerta aos veterinários, profissionais da saúde e autoridades sanitárias locais, cujos cães podem atuar como reservatórios da doença.
\end{abstract}

Palavras-chave: Canis familiaris. Diagnóstico molecular. Doença de Chagas. Tripanossomíase.

\begin{abstract}
Chagas disease, caused by the flagellate protozoan Trypanosoma cruzi, is an anthropozoonosis of great importance for public health. Several species of mammals are reservoirs for this parasite, including dogs. The objective of this work was to verify the natural infection by $T$. cruzi in the population of dogs of the municipality of Ituberá, Bahia. A total of 392 domiciled dogs from all districts of the city were evaluated; five milliliters of blood was collected from the dogs for molecular diagnosis. T. cruzi DNA was amplified through the polymerase chain reaction (PCR); the primers P35 and P36, which amplify a fragment of $330 \mathrm{bp}$, were used. The PCR products were subjected to $2 \%$ agarose gel electrophoresis containing Sybr (Invitrogen). Of the 392 dogs evaluated, only $2(0.51 \%)$ animals, one male and one female, tested positive for $T$. cruzi. This study concluded that there are dogs naturally infected by T. cruzi in the municipality of Ituberá-Bahia and that this finding is an alert to veterinarians, health professionals, and local health authorities that their own dogs can act as reservoirs of the disease.
\end{abstract}

Key words: Canis familiaris. Molecular diagnostics. Chagas disease. Trypanosomiasis.

\footnotetext{
${ }^{1}$ Discentes de Doutorado em Ciência Animal, Universidade Estadual de Santa Cruz, UESC, Ilhéus, BA, Brasil. E-mail: grazielabaroni@hotmail.com; paulaebg@gmail.com; thaissince87@hotmail.com

2 Bolsista de Pós-Doutorado PNPD/CAPES, UESC, Ilhéus, BA, Brasil. E-mail: fabiouesc@gmail.com

3 Profs. Pleno, UESC, Ilhéus, BA, Brasil. E-mail: gralbu@uesc.br; fabiana.lessa@gmail.com

* Author for correspondence
}

Received: May 19, 2017 - Approved: Nov. 17, 2017 
Chagas' Disease or American Trypanosomiasis (COURA; BORGES-PEREIRA, 2010) is caused by the protozoan, Trypanosoma cruzi (SOUZA et al., 2010). This anthropozoonosis is endemic in some Latin American countries; however, there has been an increased detection of the parasite in non-endemic countries, such as the United States, Canada, several European countries, and some Western Pacific countries (WHO, 2017).

Transmission to vertebrate hosts occurs mainly after after stinging and blood ingestion, through direct contact with feces (BAHIA et al., 2002) contaminated with hematophagous insects of the Reduviidae family (SOUZA et al., 2010), and by oral and transplacental transmission (OPAS, 2009), blood transfusion, and organ transplantation (SOUZA et al., 2010).

It is estimated that 6-7 million people in the world are infected with T. cruzi (WHO, 2017). This chronic disease affects 2-3 million people in Brazil and has become a major public health problem in the country (MINISTÉRIO DA SAÚDE, 2014). An epidemiological study conducted in Brazil between 1975 and 1980 by Camargo et al. (1984) showed that the states with the highest seroprevalence of infection in the country were Rio Grande do Sul (8.84\%), Minas Gerais (8.83\%), Goiás (7.40\%), Sergipe (5.97\%), and Bahia (5.44\%). A more recent study indicates that Bahia still has a high prevalence of T. cruzi infection in humans with a seroprevalence that varies from 5.4-25\% (ARAS et al., 2002).

Previous studies have already shown that dogs are naturally infected by this protozoan (GÜRTLER et al., 2007; LEÇA-JÚNIOR et al., 2013). The main clinical signs observed in these animals are anorexia, fever, lymphadenopathy, and cardiac alterations such as myocarditis, tachycardia, severe cardiac arrhythmia (CAMACHO, 2003; NELSON; COUTO, 2006), congestive heart failure, and diastolic dysfunction (PASCON et al., 2010; SANTANA et al., 2012).

The municipality of Ituberá is endemic for
Chagas disease (SESAB, 2013). Thus, the dogs of this region may act as reservoirs and sentinels of the disease, and play an important epidemiological role. The objective of the present study was to verify the natural infection by $T$. cruzi in the population of dogs in the municipality of Ituberá-BA.

The municipality of Itubera is located in the Southern Lowlands of Bahia state $\left(13^{\circ} 43^{\prime} \mathrm{S} 39^{\circ}\right.$ $\left.08^{\prime} \mathrm{O}\right)$. The region has a hot climate with average temperatures of $25.3{ }^{\circ} \mathrm{C}$ and an annual thermal amplitude of $5.6{ }^{\circ} \mathrm{C}$, with annual rainfall varying between 1800 and $2400 \mathrm{~mm}$, distributed throughout the year. The biome of the municipality is represented by the Atlantic forest. The municipality has an approximate population of 29,273 inhabitants, a total area of $417 \mathrm{~km}^{2}$ and density of 63.73 inhabitants/ $\mathrm{km}^{2}$ (IBGE, 2016).

The sample size was calculated using the Epi Info 3.5.2 software, with an expected prevalence of $50 \%$, a $5 \%$ error, and a $95 \%$ confidence level considering the size of the canine population (392 dogs) is $12 \%$ of the population of the municipality (CIFUENTES, 1988). The samples were collected homogeneously from all the districts of the municipality, covering both the rural and urban areas from July to November 2015; this collection was based on the proportion of the population of each neighborhood in relation to the total population of the municipality. For each residence visited, a maximum of two dogs were examined. The study was approved by the Ethics Committee on Animal Use (CEUA) of the State University of Santa Cruz, under protocol 028/12.

Five milliliters of blood were collected by puncturing the cephalic or jugular vein of dogs. The samples were conditioned in tubes with anticoagulant (EDTA), refrigerated, and sent to the Veterinary Genetics Laboratory of the State University of Santa Cruz (UESC), where they were later subjected to molecular biology procedures.

Blood stored in EDTA tubes was centrifuged to obtain the leukocyte layers and the DNA was extracted by an Easy-DNA kit (Invitrogen). DNA 
was stored at $-20{ }^{\circ} \mathrm{C}$ prior to use. The DNA concentration of each sample was quantified with a NanoDrop 2000 (Thermo Scientific) for subsequent PCR. The mean and standard deviation of the DNA concentration were 140.96 and 115.08 , respectively, and the mean and standard deviation of the purity of the samples were 1.98 and 0.38 , respectively.

First, the integrity of the DNA was verified by using primers to amplify enzyme GAPDH (glyceraldehyde 3-phosphate dehydrogenase) (5' CCAAAGTTGTCATGGATGACC $3^{\prime}$ and $5^{\prime}$ CCTTCATTGACCTCAACTACAT $3^{\prime}$ ), which amplify a 400-bp fragment, as described by Birkenheuer et al. (2003). The reagents used were obtained from Invitrogen (Carlsbad, California, USA).

The $T$. cruzi DNA was amplified using primers P35: 5' AAATAATGTACGGGGGAGATGCATGA 3' and P36: 5' GGGTTCGATTGGGGTTGGTGT $3^{\prime}$, which amplify a 330-bp fragment from the region of the mini-circle of mitochondrial DNA (kDNA) (AVILA et al., 1990). The reaction conditions used were similar to those described by Avila et al. (1990). Reaction mixtures at a final volume of 25 $\mu \mathrm{L}$ were composed of 1.0X Taq DNA polymerase buffer, $1.5 \mathrm{mM}$ of $\mathrm{MgCl}_{2}, 2 \mathrm{mM}$ of each dNTP, 10 pmol of each primer, $1.5 \mathrm{U}$ of Taq DNA polymerase, and $100 \mathrm{ng}$ of genomic DNA. Invitrogen reagents (Carlsbad, California, USA) were used. The PCR conditions were as follows: denaturation at $94{ }^{\circ} \mathrm{C}$ for $1 \mathrm{~min}, 6{ }^{\circ} \mathrm{C}$ for $1 \mathrm{~min}$ for primer annealing, and final extension at $72{ }^{\circ} \mathrm{C}$ for $1 \mathrm{~min}$ for a total of 35 cycles.

DNA extracted from the epimastigote forms of the T. cruzi strain Tc II (former strain y) was used as a positive control. This DNA was kindly provided by researcher, Danielle Oliveira dos Anjos, from the Gonçalves Muniz Research Center (FIOCRUZ). Ultrapure water was used as a negative control.

The PCR products were subjected to $2 \%$ agarose gel electrophoresis and probed with Sybr (Invitrogen). The presence of bands was analyzed with the aid of a transilluminator (Loccus Biotecnologia). All extracted DNA samples were positive in the PCR for the GAPDH enzyme.

Of the 392 dogs evaluated in the present study, 2 $(0.51 \%)$, a male and a female, both from the urban area, tested positive.

There are few studies on the natural infection of dogs by T. cruzi; most research has been carried out on experimental infections and used serological tests as a diagnostic technique (BAHIA et al., 2002). Serological tests have been used due to the high costs of the PCR technique, which is used only for experimental purposes or to confirm discrepant serological results (OPAS, 2009). However, PCR results showed a low prevalence $(0.5 \%)$ of natural T. cruzi infection in dogs, corroborating the results obtained by Leça-Júnior et al. (2013), who also investigated the natural infection in domiciled dogs with the same technique and found a $0.7 \%$ infection rate.

It should be noted that according to Avila et al. (1990) and Chiari (1999), the PCR technique used is very sensitive for diagnosing infections in patients with chronic Chagas disease, and its sensitivity varied from 96 to $100 \%$ when compared to serological tests, for example (AVILA et al., 1993; WINCKER et al., 1994).

The low positivity observed in this study may be related to the fact that blood was collected only once from each animal and a single PCR reaction of the sample was performed. According to Araújo et al. (2002), these factors reduce the sensitivity of the technique. Another possibility is that some infected animals in this study were in the chronic phase of the disease with parasitemia below the detection threshold of the PCR reaction used or that they were in fact not infected. The $T$. cruzi positivity of these domiciled dogs has great epidemiological importance, since these animals can act as reservoirs of the parasite and are important sources of feeding for Triatoma infestans and other triatomines, attracting these insects into 
the domestic environment (GÜRTLER et al., 2007).

According to Gonçalves et al. (2012), of the 62 species of triatomines in Brazil, 25 are present in the state of Bahia; among these, the main vector species of Chagas disease in Brazil can be found, namely, Panstrongylus megistus, Triatoma brasiliensis, Triatoma sordida, Triatoma pseudomaculata, and T. infestans.

The region of Ituberá is located in an area that presents a transmission risk of Chagas disease (SESAB, 2013) and is home to remnants of the main vector, T. infestans, even after intense vector control in Brazil (MINISTÉRIO DA SAÚDE, 2014). In addition to $T$. infestans, there are other triatomine species in the Northeast region, such as Triatoma tibiamaculata, which was previously considered to be distributed in areas of wilderness but is currently found in households infected with $T$. cruzi; this suggests a potential risk of disease transmission to the inhabitants of the region (RIBEIRO JÚNIOR et al., 2015).

The results of this work lead to the conclusion that there are dogs naturally infected with $T$. cruzi in the municipality of Ituberá-Bahia; therefore, there is a possibility that zoonosis may occur from these infected dogs.

\section{Acknowledgements}

We thank Coordination for the Improvement of Higher Education Personnel (CAPES) for granting the scholarship during the whole period of this study.

\section{References}

ARAS, R.; VEIGA, M.; GOMES, I.; MOTA, G.; RODRIGUES, B.; RABELO, R.; GUZMAN-BRACHO, C.; MELO, A. Prevalence of Chagas' disease in Mulungu do Morro Northeastern Brazil. Arquivo Brasileiro de Cardiologia, Salvador, v. 78, n. 5, p. 441-443, 2002.

ARAÚJO, F. M. G.; BAHIA, M. T.; MAGALHÃES, N. M.; MARTINS-FILHO, O. A.; VELOSO, V. M.;
CARNEIRO, C. M.; TAFURI, W. L.; LANA, M. Followup of experimental chronic Chagas' disease in dogs: use of polymerase chain reaction (PCR) compared with parasitological and serological methods. Acta Tropica, v. 81, n. 1, p. 21-31, 2002.

AVILA, H. A.; PEREIRA, J. B.; THIEMAN, O.; PAIVA, E. de; DEGRAVE, W.; MOREL, C. M.; SIMPSON, L. Detection of Trypanosoma cruzi in blood specimen of chronic chagasic patients by polymerase chain reaction amplification of kinetoplast minicircle DNA: comparison with serology and xenodiagnosis. Journal of Clinical Microbiology, Barcelona, v. 31, n. 9, p. 2421-2426, 1993.

AVILA, H.; GONÇALVES, A. M.; NEHME, N. S.; MOREL, C. M.; SIMPSON, L. Schizodeme analysis of Trypanosoma cruzi stocks from South and Central America by analysis of PCR-amplified minicircle variable region sequences. Molecular and Biochemical Parasitology, Los Angeles, v. 42, n. 2, p. 175-188, 1990.

BAHIA, M. T.; TAFURI, W. L.; CALIARI, M. V.; VELOSO, V. M.; CARNEIRO, C. M.; COELHO, G. L. L. M.; LANA, M. Comparison of Trypanosoma cruzi infection in dogs inoculated with blood or metacyclic trypomastigotes of Berenice- 62 and Berenice-78 strains via intraperitoneal and conjunctival routes. Revista $d a$ Sociedade Brasileira de Medicina Tropical, Uberaba, v. 35, n. 4, p. 339-345, 2002.

BIRKENHEUER, A. J.; LEVY, M. G.; BREITSCHWERDT, E. B. Development and evaluation of a seminested PCR for detection and differentiation of Babesia gibsoni (Asian Genotype) and B. canis DNA in canine blood samples. Journal of Clinical Microbiology, Barcelona, v. 41, n. 9, p. 4172-4177, 2003.

CAMACHO, A. A. Cardiomiopatia chagásica em cães. In: BELERENIAN, G. C.; MUCHA, C. J.; CAMACHO, A. A. Afecções cardiovasculares em pequenos animais. São Paulo: Interbook, 2003. p. 162-165 p.

CAMARGO, M. E.; SILVA, G. R.; CASTILHO, E. A.; SILVEIRA, A. C. Inquérito sorológico da prevalênc|a de infecção chagásica no Brasil, 1975/1980. Revista do Instituto de Medicina Tropical de São Paulo, São Paulo, v. 26, n. 4, p. 192-204, 1984.

CHIARI, E. Chagas disease diagnosis using polymerase chain reaction, hemoculture and serologic methods. Memórias do Instituto Oswaldo Cruz, Rio de Janeiro, v. 94, p. 299-300, 1999. Supplement 1.

CIFUENTES, E. E. Program for the elimination of urban rabies in Latin America. Reviews of Infectious Diseases, Oxford, v. 10, n. 4, p. 689-692, 1988.

COURA, J. R.; BORGES-PEREIRA, J. Chagas disease: 100 years after its discovery. a systemic review. Acta 
Tropica, Rio de Janeiro, v. 115, n. 1-2, p. 5-13, 2010.

GONÇALVES, R. G.; GALVÃO, C.; MENDONÇA, J.; COSTA NETO, E. M. Guia de triatomíneos da Bahia. Feira de Santana: UEFS Editora, 2012. 112 p.

GÜRTLER, R. E.; CECERE, M. C.; LAURICELLA, M. A.; CARDINAL, M. V.; KITRON, U.; COHEN, J. E. Domestic dogs and cats as sources of Trypanosoma cruzi infection in rural northwestern Argentina. Parasitology, Buenos Aires, v. 134, n. 1, p. 69-82, 2007.

INSTITUTO BRASILEIRO DE GEOGRAFIA E ESTATÍSTICA - IBGE. Cidades@. Rio de Janeiro: Editora IBGE, 2016. Disponível em: <http://www. cidades.ibge.gov.br/xtras/perfil.php?lang=\&codmun= 291730\&search $=\|$ infogr $\%$ E1ficos:-informa $\%$ E7\%F5escompletas $>$. Acesso em: 18 maio 2017.

LEÇA-JÚNIOR, N. F.; ALMEIDA, V. A.; CARVALHO, F. S.; ALBUQUERQUE, G. R.; SILVA, F. L. First report of Trypanosoma cruzi infection in naturally infected dogs from southern Bahia, Brazil. Revista Brasileira de Parasitologia Veterinária, Ilhéus, v. 22, n. 1, p. 182-185, 2013.

MINISTÉRIO DA SAÚDE. Descrição da doença. Brasília: Editora MS, 2014. Disponível em: <http:// portalsaude.saude.gov.br/index.php/o-ministerio/ principal/leia-mais-o-ministerio/646-secretaria-svs/ vigilancia-de-a-a-z/doenca-de-chagas/12-doenca-dechagas/11113-descricao-da-doenca-de-chagas $>$. Acesso em: 10 maio 2017.

NELSON, R. W.; COUTO, C. G. Tripanossomíase americana. In: NELSON, R. W.; COUTO, C. G. Medicina interna de pequenos animais. Rio de Janeiro: Elsevier, 2006. p. 1266-1267.

ORGANIZAÇÃO PAN-AMERICANA DA SAÚDE - OPAS. Guia para vigilância, prevenção, controle e manejo clínico da doença de Chagas aguda transmitida por alimentos. Rio de Janeiro: PANAFTOSA-VP/OPAS/ OMS, 2009. 92 p.

PASCON, J. P. E.; PEREIRA NETO, G. B.; SOUSA, M.
G.; PAULINO JÚNIOR, D.; CAMACHO, A. A. Clinical characterization of chronic chagasic cardiomyopathy in dogs. Pesquisa Veterinária Brasileira, Seropédica, v. 30, n. 2, p. 115-120, 2010.

RIBEIRO JÚNIOR, G.; GURGEL-GONÇALVES, R.; REIS, R. B.; SANTOS, C. G. S.; AMORIM, A.; ANDRADE, S. G.; REIS, M. G. Frequent house invasion of Trypanosoma cruzi-infected triatomines in a suburban area of Brazil. Neglected Tropical Diseases, Buenos Aires, v. 9, n. 4, p. 1-10, 2015.

SANTANA, V. L.; SOUZA, A. P.; LIMA, D. A. S. D.; ARAÚJO, A. L.; JUSTINIANO, S. V.; DANTAS, R. P; GUEDES, P. M. M.; MELO, M. A. Caracterização clínica e laboratorial de cães naturalmente infectados com Trypanosoma cruzi no semiárido nordestino. Pesquisa Veterinária Brasileira, Seropédica, v. 32, n. 6, p. 536-541, 2012.

SECRETARIA DE SAÚDE DO ESTADO DA BAHIA SESAB. Situação epidemiológica da doença de Chagas, Bahia. Salvador, 2013. Disponível em: <http://www. suvisa.ba.gov.br/sites/default/files/2\% 20boletim epidemiologico \%20Chagas \%20\%5B1\%5D.pdf $>$. Acesso em: 15 maio 2017.

SOUZA, W.; CARVAlHO, T. M. U.; BARRIAS, E. S. Review on Trypanosoma cruzi: host cell interation. International Journal of Cell Biology, Londres, v. 2010, p. 1-18, 2010.

WINCKER, P.; BRITTO, C.; BORGES-PEREIRA, J.; CARDOSO, M. A.; OELEMAN, W.; MOREL, C. M. Use of a simplified polymerase chain reaction procedure to detect Trypanosoma cruzi in blood samples from chronic chagasic patients in a rural endemic area. The American Journal of Tropical Medicine and Hygiene, Cleveland, v. 51, n. 6, p. 771-777, 1994.

WORLD HEALTH ORGANIZATION - WHO. Chagas disease (American trypanosomiasis). Genebra: Editora World Health Organization, 2017. Available at: <http:// www.who.int/mediacentre/factsheets/ fs340/en/>. Accessed at: 10 may 2017. 
